\title{
Group Cohesiveness on Performance: Mediating Effect of Collective Organization Citizenship Behavior
}

\author{
Ikhsan Maksum ${ }^{1 *}$, T. Hani Handoko ${ }^{2}$, and Nur Laili Fikriah ${ }^{3}$ \\ Economic Faculty, State Islamic University Maulana Malik Ibrahim, Malang ${ }^{1}$; \\ Faculty of Economics and Business, Gadjah Mada University, Yogyakarta ${ }^{2}$; \\ Faculty of Economics and Islamic Business, State Islamic Institute, Tulungagung ${ }^{3}$ \\ Email: \\ ikhsan.maksum@uin-malang.ac.id; hanihandoko@ugm.ac.id; laili07f@gmail.com
}

\begin{abstract}
Organizational Citizenship Behavior towards Organizations (OCBO) concerning the organization's benefits in general and Organizational Citizenship Behavior towards Individuals (OCBI) concerning specific benefits obtained by individuals in the organization and contributes to the organization. The research aims to examine the role of mediating the collective organizational citizenship behavior on the influence of group cohesiveness on group performance based on social exchange theory and social identity theory. The object of research is working groups on the creative industries in Yogyakarta. The study used field settings and cross-sectional study designs. Research respondents were 39 working groups consisting of 300 group members and using the regression analysis technique as a research hypothesis testing technique. The results showed that collective organizational citizenship behavior (OCBO and OCBI) partially mediated the effect of group cohesiveness on group performance.
\end{abstract}

Keywords: Group cohesiveness, collective organizational citizenship behavior, group performance, social exchange theory, and social identity theory.

\begin{abstract}
Abstrak: Perilaku Kewarganegaraan Organisasi terhadap Organisasi (OCBO) mengenai manfaat organisasi secara umum dan Perilaku Kewarganegaraan Organisasi terhadap Individu (OCBI) mengenai manfaat khusus yang diperoleh oleh individu dalam organisasi, tetapi juga berkontribusi pada organisasi. Penelitian ini bertujuan untuk menguji peran mediasi perilaku kewargaan organisasi kolektif pada pengaruh kekohesifan kelompok pada kinerja kelompok berdasarkan teori pertukaran sosial dan teori identitas sosial. Objek penelitian adalah kelompok kerja pada industri kreatif di Yogyakarta. Penelitian ini menggunakan field setting dan desain studi cross-sectional. Responden penelitian adalah 39 kelompok kerja yang terdiri dari 300 anggota kelompok dan menggunakan teknik analisis regresi sebagai teknik pengujian hipotesis penelitian. Hasil penelitian menunjuGCan bahwa perilaku kewargaan organisasi kolektif (OCBO dan OCBI) secara parsial memediasi efek kekohesifan kelompok terhadap kinerja kelompok.
\end{abstract}

Kata kunci: Kohesifan kelompok, perilaku kewargaan organisasional kolektif, kinerja kelompok, teori pertukaran sosial dan teori identitas sosial. 


\section{INTRODUCTION}

Since the researchers introduced the concept of organizational citizenship behavior in recent decades, the researchers' interest in the Literature of Organizational Citizenship Behavior (OCB) has increased because it can link to the context of performance (Rubin et al., 2013). OCB became one of the most extensively studied study topics in organizational behavioral literature (Podsakoff et al., 2013). OCB is considered necessary in the organizational behavioral literature, as it becomes an essential part of employee performance (Podsakoff et al., 2013). OCB deals with employee activities to support prosocial behavior in the work environment, thus supporting performance improvement (Rubin et al., 2013). OCB is behavior that comes out of an employee's job description and engages in a behavior, such as helping others, taking on additional responsibilities, taking additional working hours, maintaining the organization, and talking about critical organizational issues (Bolino et al., 2013).

In a review of articles written by (Podsakoff et al., 2013), William and Anderson have argued that $\mathrm{OCB}$ can be distinguished based on who benefits from such behavior. Organizational citizenship behavior towards organizations (OCBO) relates to the benefits that organizations generally get, and organizational citizenship behavior towards individuals (OCBI) relates to the specific advantages gained by individuals within the organization and indirectly contribute to the organization. A common form of citizenship behavior identified as OCBI is helping behavior and courtesy, and in OCBO is a civic virtue, sportsmanship, and conscientiousness (Nielsen et al., 2012).

The comprehensive review states that most researchers focus only on individual-level organizational citizenship behavior (Gong et al., 2010). Individual-level OCB aggregation at the collective OCB or group level is essential since OCB occurring at the individual level usually has a limited impact and should, the group can be an antithesis of the effectiveness of work and task performance (Park et al., 2017). When OCB is associated with a group phenomenon, it can provide a clearer picture of the extra-role behavior in individuals in the working group. Extra role behavior requires others to trigger the exchange of roles owned by a person, with the absence of co-workers in the group, extra-role behavior can play a better role. Some studies show a positive relationship between collective organizational citizenship behavior and group effectiveness (Sawitri et al., 2016). Other research shows a positive influence of OCB on group performance (Rubin et al., 2013; Park et al., 2017).

Organizational citizenship behavior can play a better role if associated with grouplevel phenomena (Park et al., 2017). Evidence that organizational citizenship behavior can divert at the group level has to discuss in previous studies (Nielsen et al., 2012; Podsakoff et al., 2013; Park et al., 2017). However, empirical studies focus only on several dimensions of organizational citizenship behavior, such as helping behavior (Bachrach et al., 2006). Other researchers are adding good citizenship and sportsmanship (Nielsen et al., 2012). Empirical evidence tests only a small fraction of OCB dimensions. In contrast, there are still many dimensions already identified, namely about thirty dimensions that are likely to influence group performance (Podsakoff et al., 2013). The study used five dimensions of OCB, namely, helping behavior and courtesy, civic virtue, sportsmanship, and conscientiousness (Podsakoff et al., 2013). This research uses the five-dimensional OCB of (Podsakoff et al., 2013). What is more, these five dimensions have confirmed OCB's main 
dimensions (Rubin et al., 2013), which are too used to describe OCB constructs in various studies involving performance (Sawitri et al., 2016).

Researchers listed group cohesiveness variables as predictors of group performance (Park et al., 2017; Lvina et al., 2015). Group cohesiveness became one of the most studied constructs in the literature related to group performance. Researchers define group cohesiveness as a dynamic process that reflects a tendency to stick together and emphasizes unity in pursuit of instrumental objectives or satisfaction with members' affective needs (Mathieu et al., 2015). However, most importantly, the group's cohesiveness, definition, and way of measuring it have remained a contentious and controversial question since the 1950s (Park et al., 2017). With the debate, the group's cohesiveness construct deserves to reexamine to explain its constructed position to clarify its contribution to the group's performance. What is more, the group's cohesiveness constructs considered to be an essential predictor for group performance (Park et al., 2017).

Researchers included the role of mediating collective organizational citizenship behavior on the influence of group robustness on group performance. Previous studies have explained that there is a positive influence of group cohesiveness on group performance (Rubin et al., 2013; Sawitri et al., 2016; Park et al., 2017), but the question is, does the effect occur directly, or are there other factors involved in that influence?

The research uses the basis of significant theories, namely social exchange theory and social identity theory. The theory of social exchange (Blau, 1964) used to explain the phenomenon of group cohesiveness, that cohesive groups can show positive and sustainably associated with social exchange when compared to un cohesive groups. At the same time, social identity theory (Stets and Burke, 2000) used to reinforce the opinion that cohesive groups can show a significant correlation to some outputs such as group performance and group effectiveness (Chiniara and Bentein, 2017).

Researchers used purposive sampling, 39 groups consisting of 300 working group members in Yogyakarta's creative industries as research objects. The working group expects to provide an overview of the phenomenon of collective organizational citizenship behavior that wants to research. The working group's selection based on the reason that the working group in the creative industries prefers the group's work to complete the tasks provided by the organization and the group members may also help colleagues if there are difficulties in the work and outside of work. What is more, these working groups are more creative oriented in the work of projects. With these characteristics, it expects to photograph the phenomenon of collective organizational citizenship behavior currently being studied.

The study's purpose was to test the role of collective organizational citizenship behavior mediation on the influence of group cohesion on group-level performance and to use field setting and cross-sectional study design (Podsakoff et al., 2013). Most studies that test the influence of organizational citizenship behavior and its output use an individual level. That fact is not surprising, given that testing group-level phenomena are harder to do (Podsakoff et al., 2013). This study's analytical techniques are regression to estimate research models that use mediating and moderation (Podsakoff et al., 2013).

\section{THEORETICAL REVIEW}

The Effect of Group Cohesiveness on Group Performance. The basis of social exchange theory (Blau, 1964) uses to explain that cohesive groups can show more positively and 
sustainably about social exchange than un cohesive groups (Chiniara and Bentein, 2017). In other words, norms of behavior cannot be found well in groups that have un cohesive. That is, the group's cohesiveness intends to create stimulation for each member in order to be willing to engage in the exchange of extra-role behavior (OCB). Thus, there can be no exchange of extra-role behavior in groups that have low group cohesiveness. Social exchange relationships can become weaker when the group cohesiveness is weak (Chiniara and Bentein, 2017).

Social identity theory serves as a supporting theory, which explains that social groups collect individuals who hold a general social identification or view of themselves as the same category of social members (Stets and Burke, 2000). This supporting theory describes the phenomenon of working groups having high cohesiveness so that each of its members can hold the same social identity and views about their collective goals. Chiniara and Bentein (2017) supported the statement so that it can ultimately lead to high cohesiveness and trigger pro-social behavior or extra-role behavior and can ultimately improve the group's performance and overall group effectiveness (Mathieu et al., 2015).

Group cohesion is an aspect that needs to emphasize in this study since group cohesiveness can support performance improvement (Lvina et al., 2015; Mathieu et al., 2015; Chiniara and Bentein, 2017). A cohesive group is a group with members who are "always together," members are bound by other members and maintain social interaction (Lvina et al., 2015). Group co-dependence has characteristics based on feelings of solidarity, harmony, and commitment between each member and connected (Goodman et al., 1987), a deep feeling that describes the meaning of "we" instead of "me." With strong social interaction, the working group can show strong social bonds (Lvina et al., 2015).

In the previous literature, group cohesion conceptualize as a group member's commitment to group tasks. The group cohesiveness concept was very close to the group's performance and actual group effectiveness (Lvina et al., 2015). Thus, group cohesiveness becomes a relevant factor for predicting group performance (Park et al., 2017). Logically, group coordination can affect performance through improved coordination between group members and improve the overall smooth operation system. In other words, the group with high cohesiveness had better performance than the group with low cohesiveness.

According to the social exchange (Blau, 1964), a group with high cohesiveness can make each group member have a high trust and a sense of unity. The trust and sense of togetherness resulted from the social interaction of each member of the group who had high confidence. Furthermore, group members can be more active in coordinating and communicating and contributing to their co-workers and working groups (Lvina et al., 2015; Park et al., 2017). Ultimately, logically, the group's performance can improve. On the other hand, when a group member has a cohesiveness, then each member feels they have a strong bond with their co-workers and a robust social exchange. Subsequently, the member always experiences high satisfaction or high organizational commitment. Furthermore, efficiency and creativity increase. With the logic of thinking can be compiled the first hypothesis, namely:

H1: Group cohesiveness positively affects group performance. 
The Role of Mediating Collective Organizational Citizenship Behavior on the Effect of Group Cohesiveness on Group Performance. Current research has a basic assumption that group context can affect group members' attitudes and behavior within it (Rubin et al., 2013), and the effect occurs through strong social interactions between members directly (Lvina et al., 2015). An essential part of a working group is the emergence of its members' social identity and a pattern based on dependency and is usually called group cohesiveness (Chiniara and Bentein, 2017). Following social identity theory, members can choose suitable groups or following their social identity. When a person finds a group that suits them, they try to defend themselves as group members based on strong emotional bonds and characteristic compatibility (Chiniara and Bentein, 2017). Furthermore, the existence of a strong emotional bond and the suitability of characteristics makes each member willing to take an extra-role (OCB) to achieve collective goals. In the end, group performance and group effectiveness can be achieved well (Park et al., 2017).

Organizational citizenship behavior (OCB) is freedom in behavior, not directly or explicitly recognized by a formal reward system (Organ, 1997). In other words, OCB is a form of behavior that comes out of an employee's job description and engages in certain behaviors, such as helping others, taking additional responsibilities, taking additional hours of work, maintaining the organization, and talking about important issues related to the organization (Bolino et al., 2013).

This study places organizational citizenship behavior as a mediating variable for the effect of group cohesiveness on group performance. Logically, when the workgroup has high cohesiveness, then group members have a more substantial commitment to complete the assigned task and achieve group goals. Group members are more willing to help colleagues (Chiniara and Bentein, 2017). The higher the cohesiveness, it can make the more member willing to help and take extra-roles to achieve common goals. Performance increases (e.g., time efficiency, resources, and creativity), and encourage the working group to develop work strategies, fill member motivation, and improve communication between members (Chiniara and Bentein, 2017).

Based on social exchange theory and social identity theory, cohesive groups show better and more sustainable social exchange than groups with low cohesiveness. More cohesive groups show increased identification and more significant social influence in achieving collective goals (Park et al., 2017) because organizational citizenship behavior can reflect group members' efforts to maintain social exchange relationships within the group instead of economic exchanges. Citizenship behavior can improve performance through a social lubrication process, and reduce social barriers between members, improving group performance (Organ, 1997). Also, groups that have high cohesiveness have their members also have a strong social identity that can trigger emotional relationships between members (Chiniara and Bentein, 2017). in social interaction and psychological interaction when compared with groups that have low cohesiveness. This relationship ultimately leads to pro-social behavior and extra-role behavior among group members and ultimately affects group performance (Chiniara and Bentein, 2017; Sawitri et al., 2016). From the logic of thinking, a second hypothesis can make.

H2: a) Organizational citizenship behavior at collective individuals, and b) Organizational citizenship behavior at collective organizations mediate the effect of group cohesiveness on group performance. 
H1

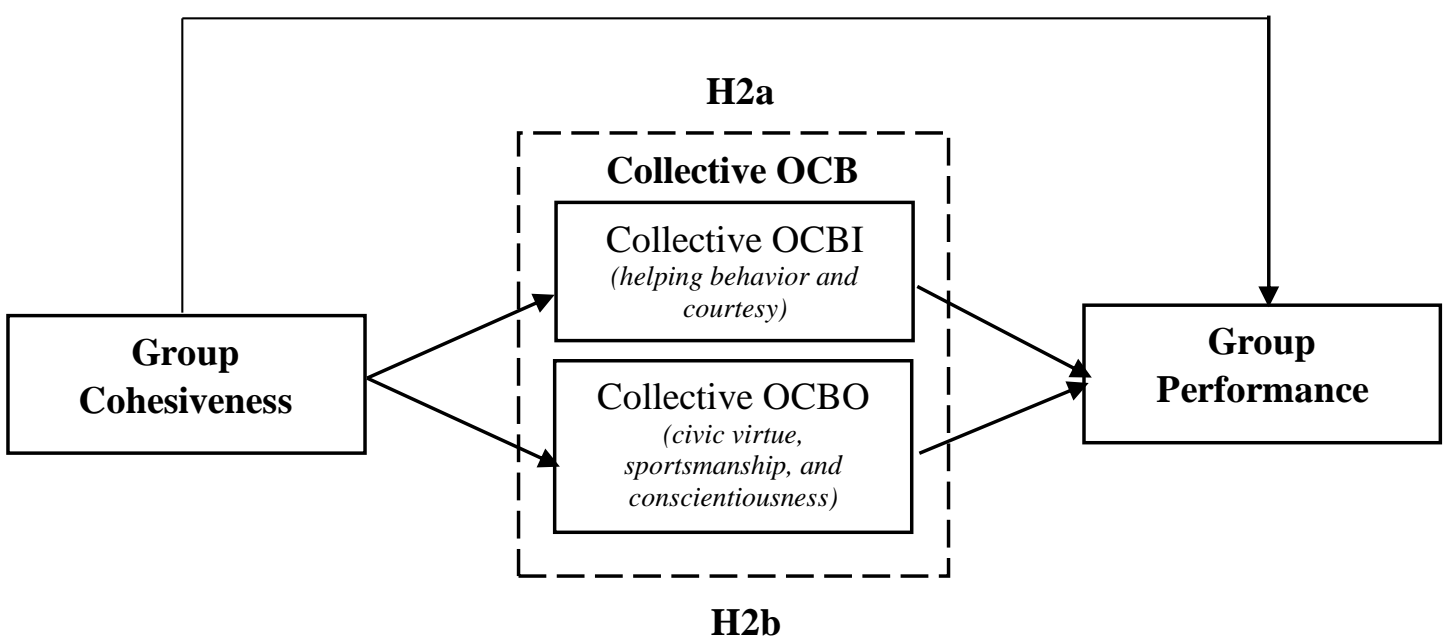

Figure 1. Research Framework

Source: Secondary data processed, 2018

The research model shows that the group cohesiveness variable can directly affect group performance; on the other hand, it also indirectly influences it through the mediating variables of collective organizational citizenship behavior (collective OCBI and collective OCBO).

\section{METHODS}

This research uses a positivistic paradigm that prioritizes causality between variables (Aliyu et al., 2014) with a quantitative deductive approach. This research is cross-sectional to collect data at a specific time to answer the questionnaire, to take a picture of the phenomenon at that one time, and to confirm the hypotheses that have been compiled (Cooper and Schindler, 2014). The study population uses any existing workgroups in creative industry companies in Yogyakarta. Meanwhile, the sample taken was 39 working groups (Sekaran, 2003) consisting of 300 individuals who are creative industry companies in Yogyakarta in game creation, graphic design, robotics, software developer, and web designers.

The questionnaire using as a tool for data collection. Data using primary data. While the sampling technique uses probability sampling, and respondents determined using purposive sampling because of sampling base on specific characteristics (Cooper and Schindler, 2014). The characteristics of the sample referred to are, the respondent must have a working group, must work in groups for at least three months, and have been involved and completed the task at least once.

The independent variable in this study is group cohesiveness. The conceptualization of group cohesiveness is the commitment to group tasks (Goodman et al., 1987), and a sense of connection to describe the word "we" not "me." The group cohesiveness measure has six measurement items, one of which is "Our group is one unit in trying to achieve performance" and "Our workgroup members never take the time to go out together outside of working hours (R)." 
The mediating variable uses collective organizational citizenship behavior variables. The conceptualization of collective organizational citizenship behavior (OCB) is freedom in behavior, not directly or explicitly recognized by its formal reward system (Organ, 1997). OCB is "extra-role" behavior that comes out of an employee's job description and engages in behaviors such as helping others, taking additional responsibilities, taking additional hours of work, maintaining the organization, and talking about important issues related to the organization (Bolino et al., 2013). The collective organizational citizenship behavior measure (OCB) has twenty items of measurement, one of which is "We try to avoid causing trouble to our colleagues" and "We are always ready to assist the people around us."

The dependent variable uses the group performance variable. The conceptualization of group performance is the improvement of coordination between members. It can improve the workgroup's smooth operation (Mathieu et al., 2015) to improve coordination between members to achieve collective goals and objectives. The group performance measurement has five measurement items, one of which is "We think it works better together" and "Willing to work together in the future."

Data collected through a questionnaire. This questionnaire is distributed to respondents directly to respondents who meet the criteria determined by the researcher. The questionnaire includes questions such as "Do you have a working group?" if the answer is "Yes" then the respondent can continue filling out the questionnaire. To measure variables at a higher level, the technique that can use is the Direct Consensus Approach, which is an agreement or consensus between individuals at a lower level (Chan, 1998). The Direct Consensus Approach to providing answers to one questionnaire based on each group's agreement. The answers to the questionnaire obtained can represent all members of the work team. The second way researchers can provide one questionnaire for each group member is to fill out the questionnaire. The overall answers obtained will be processed by calculating each group's average to obtain a group consensus when the respondent can not discuss it at a specific time. Data collection carried out at group level research is not much different from research conducted at the individual level. (Chan, 1998) asserts that the Direct Consensus Approach is an appropriate technique used in research involving group-level data.

The researcher used item scales adjusted at the group level by considering the feasibility of aggregating individuals' responses as a working group in the Yogyakarta creative industry company. Researchers determined the Inter-Rater Agreement (IRA) as an index of approval for each other in a workgroup (James et al., 1993), while the standard value that must be met for each group separately was rwg. $>0.70$, and the highest score reached 1. A high rwg. score indicates that the workgroup has sufficient approval to support individual-level phenomena' aggregation to represent the group level. It is not included in the analysis process if the workgroup cannot meet the standard score $(<0.70)$. Furthermore, the researcher calculated Inter-Class Correlation (ICC (1) and ICC (2)) using a One-Way Random for each respondent to describe the research variables (e.g., group cohesiveness, collective organizational citizenship behavior, and group performance). The ICC value (1) has a standard of $>0.05$, and ICC (2) is $>0.60$ to represent the mean score at the group level (Chan, 1998). The ICC (1) score represents the adequacy of the variance between groups. When the standard value can meet, the ICC (1) value can represent the adequacy of variance between groups to support the aggregation of individual data to represent group phenomena. Meanwhile, the ICC (2) score represents the feasibility of a workgroup response based on 
the average score given by each member of the workgroup to represent a score at the group level (Chan, 1998).

Researchers used the validity test to ensure that the scale used was following the conceptual, dimensional definition, and met the required reliability (Hair et al., 2014). The validity test uses Face Validity and Content Validity (Hair et al., 2014). Discussing or consulting with experts in their fields aim to adapt the research instrument to the current research context (Hair et al., 2014). Whereas in content validity, the researcher adjusted the overall content, definition, and research construct by reading and matching the existing literature. The researcher's purpose in conducting content validity is to adjust the conceptual research variables and ensure the measurements or questionnaires used in the study (Hair et al., 2014). Researchers perform face validity and content validity before the CFA testing phase because without understanding the meaning or content of each item, it is impossible to correctly express and specify in a measurement theory (Hair et al., 2014)

Furthermore, Confirmatory Factor Analysis (CFA) and Discriminant Validity are used to confirm the factors that describe the variable group cohesiveness, collective organizational citizenship behavior, and group performance, which have differences (Hair et al., 2014: 602) based on standardized loading of > 0.50. and, ideally, 0.70 (Hair et al., 2014: 605). CFA was used to confirm the factors used in each research construct. The researcher confirmed that the factors included in the group cohesiveness, group performance, and collective organizational citizenship behavior differed from one another and created a pattern generated by the factor loading. When the loading factor for each variable correlates, the researcher can eliminate correlated items because they cannot explain a research construct. Whereas in discriminant validity testing, researchers tested whether the constructs had differences with other constructs; this is because in testing latent variables, researchers often found similarities between behavioral research variables (Hair et al., 2014).

The reliability test use to know whether the measurement instrument was consistent, accurate, and precise regarding the Cronbach's Alpha value of 0.60 to 0.70 (Hair et al., 2014). Furthermore, the researcher conducted a multicollinearity test to test whether there was a high correlation between the independent variables included in the research model to minimize the impact of the small regression coefficient score and increase the standard error so that there was no significance in the testing between variables. (Baron and Kenny, 1986) state that testing the hypothesis that uses the mediating variable it must be tested between the independent and the mediating variable to the dependent variable to ensure a relationship between variables based on the Variance Inflation Factor score of $>1$ or $<10$ and Tolerance score is more than 0.10 (Ghozali, 2006). With this assumption, the mediating variable can be treated as an independent variable, so a multicollinearity test is needed to ensure that each variable has no relationship with one another.

Finally, the researcher analyzed the data using multiple regression techniques. The multiple regression function in research includes three latent variables (e.g., group cohesiveness, collective organizational citizenship behavior, and group performance) and only can observed through specific indicators to describe the variables as a whole. Researchers tested the mediating role of collective OCB with a testing mechanism based on a concept developed by (Baron and Kenny, 1986). The testing stages begin with directly examining the independent variable (GC) effect on the dependent variable (GP). Second, the independent variable (GC) direct tested on the mediator variable (OCBI and OCBO). 
Third, directly test the mediator variables (OCBI and OCBO) on the dependent variable (GP). In the last stage, the researcher tested the independent variable (GC) and the mediator variable (OCBI and OCBO) simultaneously on the dependent variable (GP). In the mediation test, the researcher observes the significance test parameters in the standardized coefficient and sig tables, not the coefficient tables commonly observed indirect testing. Observations made because the mediation test did not only consider testing the independent variable's direct effect on the dependent variable but also needed to consider the independent variable's indirect effect on the dependent variable through the mediator variable (Jogiyanto, 2011; 104).

\section{RESULTS}

Researchers collected data using a questionnaire survey on creative industry companies in Yogyakarta. It is possible to obtain a larger volume of data in a relatively short time and at lower costs. The results can refer to in the research questionnaire distribution table.

When referring to the table of the researcher's 350 questionnaires, only 300 questionnaires can be analyzed or about $87.7 \%$. The 300 respondents consist of six creative industries, such as web developers, software developers, game developers, animation, robotics, and graphic design.

Table 1. Distribution of Research Questionnaires

\begin{tabular}{|c|c|c|c|}
\hline Information per Individual & \multicolumn{2}{|c|}{ Total } & Percentage $(\%)$ \\
\hline Questionnaire & \multicolumn{2}{|c|}{350} & 100 \\
\hline Returned Questionnaires & \multicolumn{2}{|c|}{315} & 90 \\
\hline Non-Returned Questionnaires & \multicolumn{2}{|c|}{35} & 10 \\
\hline The questionnaire that cannot be analyzed & \multicolumn{2}{|c|}{15} & 4.3 \\
\hline The questionnaire that can be analyzed & \multicolumn{2}{|c|}{300} & 87.7 \\
\hline Information per Group & Group & Members & Percentage $(\%)$ \\
\hline Web developer & 6 & 43 & 14.4 \\
\hline Software developer & 5 & 38 & 12.6 \\
\hline Game developer & 6 & 47 & 15.6 \\
\hline Animation developer & 7 & 56 & 18.6 \\
\hline Robotics & 7 & 52 & 17.4 \\
\hline Graphic design & 8 & 64 & 21.4 \\
\hline Total & 39 & 300 & 100 \\
\hline
\end{tabular}

Source: Primary data processed, 2020

Furthermore, researchers used validity and reliability tests to assess whether the instrument was able to measure what wanted to measure in scientific research (Cooper and Schindler, 2014). The validity test uses face validity and content validity to adjust research indicators to the current context. The construct validity test uses confirmatory factor analysis based on the KMO test results, a minimum of 0.5. The results achieved from the KMO test were 0.816 . 
Table 2. KMO and Bartlett's Test

\begin{tabular}{lll}
\hline Kaiser-Mayer-Olkin & & 0.816 \\
Sample adequacy & & \\
Bartlett's Test of Sphericity & Approx. Chi-Square & $4.401 \mathrm{E} 3$ \\
& Df & 463 \\
& Sig. & 0.000 \\
\hline Source: Primary data processed, 2020 & &
\end{tabular}

Another criterion is using factor loading analysis. If a question item has a loading factor of $>0.5$, it means that it can use in research (Hair et al., 2014). The validity test results show that the loading factor value of each measurement item is $>0.5$. The results of the test details can reference in the table. The EVA test results of the group cohesiveness variable were 0.992; the Collective OCBI variable of got a score of 0.974. Furthermore, Collective OCBO variable got a score of 0.986 , and the group performance variable got a score of 0.994 .

Table 3. Validity Test and Reliability Test

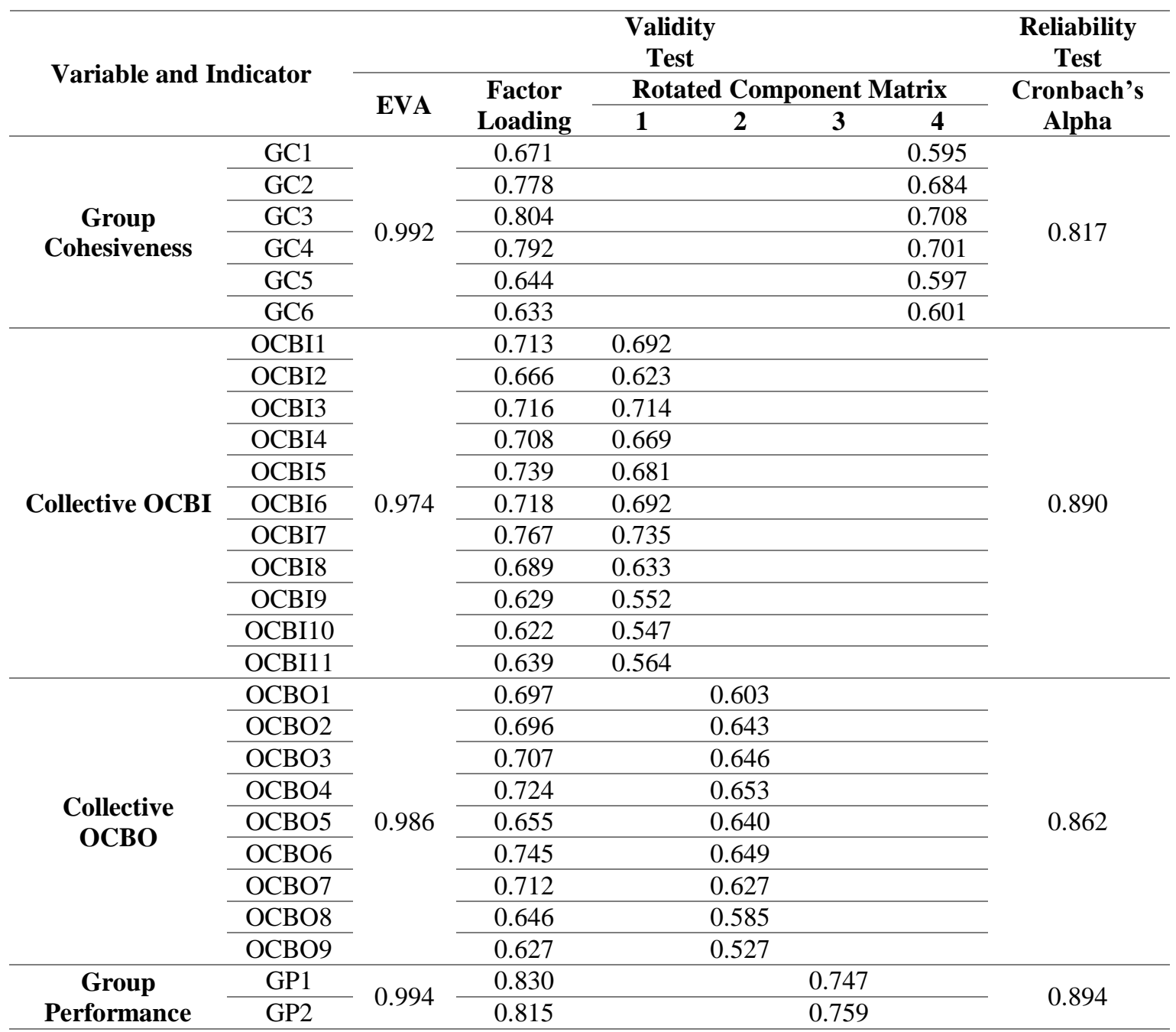




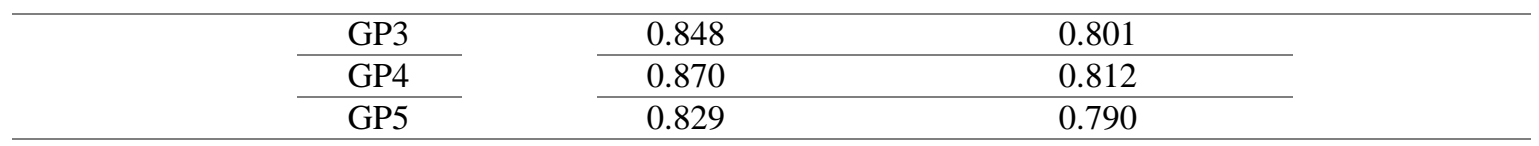

Source: Primary data processed, 2020

Furthermore, the researchers carried out confirmatory factor analysis (CFA) in testing the feasibility of measuring the variables that represent the smallest number of constructs to differentiate between one variable and another (Hair et al., 2014), and if each variable has a difference, it can create the pattern generated by its factor loading score. Factor loading in the rotated component matrix column, which shows the construct of cohesiveness of groups which have six factors grouped into one unit and each factor gets a score greater than 0.50 (GC1: 0.595; GC2: 0.684; GC3: 0.708; GC4: 0.701. ; GC5: 0.597; GC6: 0.601). The construct of collective individual organizational citizenship behavior which has eleven factors is also grouped into one unit and each factor scores more than 0.50 (OCBI1: 0.692; OCBI2: 0.623; OCBI3: 0.714; OCBI4: 0.669; OCBI5: 0.681; OCBI6: 0.692; OCBI7: 0,735; OCBI8: 0,633; OCBI9: 0,552; OCBI10: 0,547; OCBI11: 0,564). The construct of collective organizational citizenship behavior has nine factors that are grouped into one and each factor scores more than 0.50 (OCBO1: 0.603; OCBO2: 0.643; OCBO3: 0.646; OCBO4: 0.653; OCBO5: 0.640; OCBO6: 0.649: OCBO7: 0.627; OCBO8: 0.585; OCBO9: 0.527). the performance construct of a group with five factors grouped into one unit gets a score of more than 0.50 (GP1: 0.747; GP2: 0.759; GP3: 0.801; GP4: 0.812; GP5: 0.790).

In addition to using the validity test, researchers also tested reliability based on Cronbach's Alpha values, ranging from 0.60 to 0.70 (Hair et al., 2014). The group cohesiveness variable resulted in a score of $\alpha$ 0.817. The collective individual, organizational citizenship behavior variable obtained a score of $\alpha 0.890$. The organizational citizenship behavior variable of the collective organization obtained a score of $\alpha 0.862$. Furthermore, the group performance variable obtained a score of $\alpha 0.894$. Technically, the instruments used are reliable.

After testing the validity and reliability, the researchers conducted data aggregation analysis and measurements. In the first step, the researcher estimates the value of the InterRater Agreement. The results obtained from 39 working groups have met the specified minimum score standard (cut-off $>0.70$ ), which means that the entire working group has met the testing and analysis process requirements. In the next step, the researcher calculates the ICC (1) and ICC (2) or commonly referred to as inter-class correlation using one-way random. The ICC calculation (1) for the group cohesiveness variable is 0.427 . The collective individual, organizational citizenship behavior variable gets a score of 0.424 . The collective organizational citizenship behavior variable gets a score of 0.410 , and then the group performance variable has the highest score of 0.627 . Overall, each variable fulfills the minimum requirements with a cut-off value of 0.05 , which means that each group can represent group level testing. In the ICC test (2), a score of $>0.60$ must be sufficient (Chan, 1998). The results of testing the group cohesiveness variable were 0.817 . The collective individual, organizational citizenship behavior variable was 0.890 , while the collective organizational citizenship behavior variable was 0.862 , and then the group performance variable got a score of 0.894 . 
Table 4. Inter-Class Correlation Test (ICC (1) \& ICC (2))

\begin{tabular}{ccc}
\hline Variable & ICC 1 & ICC 2 \\
\hline GC & 0.427 & 0.817 \\
OCBI & 0.424 & 0.890 \\
OCBO & 0.410 & 0.862 \\
GP & 0.627 & 0.894
\end{tabular}

Source: Primary data processed, 2020

In the next stage, the researcher conducted a multicollinearity test to determine whether the variables used in the study had reached the criteria for hypothesis testing. The multicollinearity test value refers to a Variance Inflation Factor (VIF) score of less than ten and a Tolerance score of more than 0.100 .

Table 5. Multicollinearity Test

\begin{tabular}{lccc}
\hline \multicolumn{1}{c}{ Variable } & Tolerance Score & VIF Score & Information \\
\hline GC & 0.100 & 1.000 & There is no multicollinearity \\
\cline { 2 - 4 } OCBI & 0.501 & 1.997 & There is no multicollinearity \\
OCBO & 0.979 & 1.021 & There is no multicollinearity \\
\hline \multicolumn{2}{l}{ Dependent Variable: GP } & & \\
Source: Primary data processed, 2020 &
\end{tabular}

Based on the multicollinearity test table, it can be that the group cohesiveness variable test gets a VIF score of 1,000 and a tolerance of 0.100 . The collective organizational citizenship behavior variable obtained a VIF score of 1.997 and a Tolerance score of 0.501 . Furthermore, in testing the organizational citizenship behavior variable, the collective organization obtained a VIF score of 1.021 and a Tolerance score of 0.979 . Thus, each variable has met the minimum requirements to be free from multicollinearity deviations.

After the data aggregation and multicollinearity test stages, then the authors test the hypothesis, which consists of several stages based on the testing mechanism of (Baron and Kenny, 1986).

Table 6. Hypothesis Regression Test

\begin{tabular}{|c|c|c|c|c|c|}
\hline Hypothesis & Effect & $\mathbf{R}$ & R Square & $\begin{array}{l}\text { Standardized } \\
\text { coefficient }(\beta)\end{array}$ & Sig. \\
\hline H1 (+) & $\mathrm{GC} \rightarrow \mathrm{GP}$ & 0.545 & 0.297 & 0.545 & 0.001 \\
\hline \multirow{5}{*}{ H2a (+) } & $\mathrm{GC} \rightarrow \mathrm{GP}$ & 0.545 & 0.297 & 0.545 & 0.001 \\
\hline & $\mathrm{GC} \rightarrow \mathrm{OCBI}$ & 0,707 & 0,499 & 0,707 & 0,001 \\
\hline & $\mathrm{OCBI} \rightarrow \mathrm{GP}$ & 0,504 & 0,254 & 0,504 & 0,001 \\
\hline & $\mathrm{GC} \rightarrow \mathrm{GP}$ & \multirow{2}{*}{0,570} & \multirow{2}{*}{0,329} & 0,237 & 0,001 \\
\hline & $\mathrm{OCBI} \rightarrow \mathrm{GP}$ & & & 0,378 & 0,001 \\
\hline \multirow{5}{*}{ H2b (+) } & $\mathrm{GC} \rightarrow \mathrm{GP}$ & 0.545 & 0.297 & 0.545 & 0.001 \\
\hline & $\mathrm{GC} \rightarrow \mathrm{OCBO}$ & 0,145 & 0,21 & 0,145 & 0,012 \\
\hline & $\mathrm{OCBO} \rightarrow \mathrm{GP}$ & 0,189 & 0,36 & 0,189 & 0,001 \\
\hline & $\mathrm{GC} \rightarrow \mathrm{GP}$ & \multirow{2}{*}{0,556} & \multirow{2}{*}{0,309} & 0,112 & 0,022 \\
\hline & $\mathrm{OCBO} \rightarrow \mathrm{GP}$ & & & 0,529 & 0,001 \\
\hline
\end{tabular}

Source: Primary data processed, 2020 
Based on the table of significance test results, the group cohesiveness variable's regression test results on group performance (GC-GP) have a sig value. $0.001 ; \beta 0.545$; R2 $0.297 ; \mathrm{p}<0.05$. The regression test shows that group cohesiveness has a positive and significant effect on group performance based on the Beta value of 0.545 and $\mathrm{R}$ Square 0.297 , meaning that the variance of group performance describes group cohesiveness of $29.7 \%$ and $70.3 \%$ explained by other variables not examined in the research model. Thus hypothesis 1 is supported.

Hypothesis 2a tested group performance variables and collective individual organizational citizenship behavior on group performance simultaneously (GC and OCBI at GP). The results of these tests obtained a sig value. 0.001 and $0.001 ; \beta=0.237$ and $\beta=$ $0.378 ; \mathrm{R} 20.325 ; \mathrm{p}<0.05$. The regression results show that collective individual organizational citizenship behavior mediates the effect of group cohesiveness on group performance based on lower Beta values $(\beta=0.545$ to $\beta=0.237$ and 0.378 ). While the $R$ Square value is 0.325 , which means that the variance of collective individual organizational citizenship behavior can mediate the effect of group cohesiveness on group performance by $32.5 \%$ and $67.5 \%$ explained by variables other than the research model. Thus, hypothesis $2 \mathrm{a}$ is supported.

Furthermore, hypothesis $2 \mathrm{~b}$ testing the group cohesiveness variables and organizational citizenship behavior on group performance simultaneously (GC and OCBO at GP). The results of the test get the sig value. 0.022 and $0.001 ; \beta=0.112$ and $\beta=0.525$; $\mathrm{R} 20.309 ; \mathrm{p}<0.05$. The regression results show that collective organizations' variable organizational citizenship behavior mediates the effect of group cohesiveness on group performance based on a lower Beta value $(\beta=0.545$ to $\beta=0.112$ and $\beta=0.525)$. While the $\mathrm{R}$ Square value of 0.309 means that the variance of organizational citizenship behavior in collective organizations can mediate the effect of group cohesiveness on group performance by $30.9 \%$ and $69.1 \%$ explained by other variables besides the research model. Thus, hypothesis $2 \mathrm{~b}$ is supported.

\section{DISCUSSION}

Direct Effect of Group Cohesiveness on Group Performance. Hypothesis 1 states that group cohesiveness has a positive effect on group performance. The regression results confirm the concept put forward by (Chiniara and Bentein, 2017), which states that group cohesiveness is a commitment of each member to group tasks. Group cohesiveness is very close to group behavior, productivity, and effectiveness, efficiency, and performance because members of the workgroup have the belief that togetherness and unity can give them more power to do tasks (Mathieu et al., 2015); moreover, members in a cohesive group show more social interactions. Better than the non-cohesive group. Good social interaction can influence the creation of extra-role behavior or pro-social behavior that makes each group member willing to be involved in achieving collective goals and commit to collective tasks (Lvina et al., 2015; Park et al., 2017). In other words, the group with high cohesiveness logically also has high performance compared to the group with low cohesiveness.

Referring to social exchange theory (Blau, 1964) and social identity theory (Stets and Burke, 2000), which states that cohesive groups can show more positively and sustainably related to social exchange and have a strong social identity through interaction make group members maintain themselves to stay in their workgroup and have a high commitment to 
the task (Lvina et al., 2015). When a group has high cohesiveness, each member of the group will have a strong bond with colleagues and have social exchanges that are stronger than material exchanges, so that later in the working group, there will be a strong commitment to achieving common goals and so on efficiency, effectiveness and group performance can increase.

Based on the exchange theory used in the study, it supports that social exchanges that occur within the workgroup can trigger self-efficacy, which is the essential role of contributions between group members, to improve the overall group performance. This study shows that group cohesiveness only happens at the group level. Groups with high cohesion can reduce conflict and achieve higher performance than groups with low cohesion (Liu, 2016). Reflecting on social exchange theory, research conducted by (Bolino et al., 2010) support that social exchange between each group member can only occur in a cohesive group. In a cohesive group, each group member can provide voluntary assistance and encourage each member to be directly involved in social exchange behavior to benefit the overall group performance. Conversely, groups with low cohesiveness tend to have low group structure development and have unclear group social norms. a

Social norms that develop low group structures can cause group members to be reluctant to show social exchange behavior and destroy social ties between individuals. When social norms and social ties are disturbed, the feelings of mutual help between members also decrease, and in the end, group performance can decline (Liu, 2016). Support for the current research from (Lvina et al., 2015), which states that an individual who works independently for a specific purpose can trigger a decrease in performance when compared to someone who works in a workgroup with high cohesiveness.

Indirect Effect of Group Cohesiveness on Group Performance through Collective Organizational Citizenship Behavior. The regression test results confirm the support for hypotheses $2 \mathrm{a}$ and $2 \mathrm{~b}$. Logically, when group cohesion is described as a strong bond with other group members and a strong desire to defend themselves as part of the group, then a cohesive group has members who tend to be sensitive and are more willing to help and help colleagues (Rubin et al., 2013), and in the end, can affect group performance. High group cohesiveness also triggers the compatibility of each member. It has a feeling of being a unit so that group members are willing to help and take different roles (OCB) to achieve common goals (Sawitri et al., 2016). On the other hand, a group with low cohesiveness can also hamper the group's lubrication process. Low lubrication processes can ultimately reduce the social exchange process and increase social conflict in a workgroup, and ensure a decline in group performance. In other words, collective OCB cannot play the right role in groups that have low cohesiveness.

Referring to social exchange theory (Blau, 1964) and social identity theory (Stets and Burke, 2000) states that cohesive groups can encourage collective organizational citizenship behavior (OCBI and OCBO) to reflect the efforts of members in maintaining social and emotional exchange relationships. So that in the end, it can improve group performance through a social lubrication process. Social lubrication can occur because sensitivity arises to help colleagues in terms of work. Outside of work (Chiniara and Bentein, 2017), then when the social lubrication process occurs in the workgroup, and then group performance has increased (Rubin et al., 2013; Lvina et al., 2013) al., 2015; Park et al., 2017). The test results show that workgroups with high cohesiveness are more likely to show an excellent 
pro-social role (collective OCB). Reflecting on the social exchange theory, the pro-social role in-group members can lead to increased performance. In other words, collective organizational citizenship behavior (OCBI and OCBO) can act as a mediating variable on group cohesiveness's indirect effect on group performance to support hypotheses $2 \mathrm{a}$ and $2 \mathrm{~b}$.

\section{CONCLUSION}

Research findings confirm that group cohesiveness has a positive and significant effect on group performance. The group with higher cohesiveness logically shows higher group performance. The logical explanation regarding the effect of group cohesiveness on group performance is the feeling of solidarity, harmony, and commitment between each group member to form a strong emotional bond and ultimately increase members' commitment to complete group assignments.

Based on the research results, which states that there is an indirect effect of collective organizational citizenship behavior (OCB) on the relationship between group cohesiveness and group performance. The research findings' logical explanation is that organizational citizenship behavior as a different role that can provide a social lubrication process and moderate social barriers in a workgroup. When the workgroup has high cohesiveness, members can maintain social relationships and be more willing to take on different roles than groups with low cohesiveness. Finally, high cohesiveness groups can improve performance through continuous improvement in communication and coordination.

In line with social exchange theory (Blau, 1964) and social identity theory (Stets and Burke, 2000), when workgroups at creative industry companies in Yogyakarta have high cohesiveness, they can make members feel they have high social relations and social identity. Stronger. Social relations and social identities can facilitate communication and coordination between members of the workgroup through social lubrication so that each member is willing to take on extra roles related to tasks or outside the task to achieve collective goals. The group cohesiveness can improve group performance through the social process (collective organizational citizenship behavior). The future research will use laboratory study settings to simulate the influence of collective organizational citizenship behavior and its outcomes. This result makes it possible to obtain a more realistic picture of the phenomenon, even though laboratory testing is more difficult for researchers (Podsakoff et al., 2013).

\section{REFERENCES}

Aliyu, A.A., Bello, M.U., Kasim, R., and Martin, D. (2014). Positivist and Non-Positivist Paradigm in Social Science Research: Conflicting Paradigms or Perfect Partner? Journal of Management Sustainability, 4(4), 79.

Bachrach, D.G., Powell, B.C., Collins, B.J., and Richey, R.G. (2006). Effects of Task Interdependence on Relationship between Helping Behavior and Group Performance. Journal of Applied Psychology, 91(6), 1396-1405.

Baron, R.M., and Kenny, D.A. (1986). The Moderator-Mediator Variable Distinction in Social Psychological Research: Conceptual, Strategic, and Statistical Consideration. Journal of Personality and Social Psychology, 51: 1173-1182.

Blau, P. M. (1964). Exchange \& power in social life. New York, NY: John Wiley \& Sons. 
Bolino, M.C., Klotz, A.C., Turnley, W., and Harvey, J. (2013). Exploring the Dark Side of Organizational Citizenship Behavior. Journal of Organizational Behavior, 34, 542559.

Chan, D. (1998). Functional Relations among Constructs in the Same Content Domain at Different Levels of Analysis: A Typology of Compositions Models. The journal of social Psychology. 149: 234-246.

Chiniara, M. and Bentein, K. (2017). The Servant Leadership Advantage: When Perceiving Low Differentiation In Leader-Member Relationship Quality Influences Team Cohesion, Team Task Performance, and Service OCB. The Leadership Quarterly. 116.

Cooper, D.R., and Schindler, P.S. (2014). Business Research Method, 12ed. New York: Mcgraw-Hill.

Ghozali, I. (2006). Aplikasi Analisis Multivariat dengan Program SPSS, Edisi 4. Semarang: Badan Penerbit Universitas Diponegoro.

Gong, Y., Chang, S. and Cheung, S. (2010). High-Performance Work System and Collective OCB: A Collective Social Exchange Perspective. Human Resources Management Journal, 20: 119-137.

Goodman, P.S., Ravlin, E., and Schminke, M. (1987). Understanding Groups in Organizations. In L.L. Cummings, dan BM Staw (Eds.). Research in Organizational Behavior, 9, 121-173. Greenwich, CT: JAI Press.

Hair, J.F., Hult, G.T.M., Ringle, C.M., and Sarstedt, M. (2014). A Primer on Partial Least Squares Structural Equation Modelling (PLS-SEM). Thousand Oaks, CA: Sage.

James, L. R., Demaree, R. G., and Wolf, G. (1993). Rwg: An Assessment of within Group Inter-Rater Agreement." Journal of Applied Psychology. 78: 306309.

Jogiyanto, H. M. (2011). Konsep dan Aplikasi Structural Equation Modeling Berbasis Varian dalam Penelitian Bisnis. STIM YKPN Yogyakarta. 1: 1- 140.

Liu, D. (2016). Help Your Helping Others: The Joint Impact of Group Member Organizational Citizenship Behaviors and Group Cohesiveness on Group Member Objective Task Performance Change. Group Member Citizenship Behaviour. 1-51.

Lvina, E., Johns, G., and Vandenberghe, C. (2015). Team Political Skill Composition as a Determinant of Team Cohesiveness and Performance. Journal of Management. 1-28.

Mathieu, J. E., Kukenberger, M. R., D’Innocenzo, L., and Reilly, G. (2015). Modeling Reciprocal Team Cohesion-Performance Relationships, As Impacted by Shared Leadership and Members' Competence. Journal of Applied Psychology, 100, 713734.

Nielsen, T.M., Bachrach, D.G., Sundstrom, E., and Halfhill, R.T. (2012). The utility of OCB: Organizational Citizenship Behavior and Group Performance in a Resource Allocation Framework. Journal of Management, 32: 668-694.

Organ, D.W., Podsakoff, P.M., and Mackenzie, S.B. (2006). Organizational Citizenship Behavior: Its Nature, Antecedents, and Consequences. Thousand Oaks, CA: Sage.

Park, W., Kim, S.M., and Gully, M.S. (2017). Effect of Cohesion on the Curvilinear Relationship Between Team Efficacy and Performance. Small-Group Research. 1-27.

Podsakoff, N.P., Philip, M.P., Mackenzie, S.B., Maynes, D.T., and Spoelma, T.M. (2013). The consequence of Unit-Level Organizational Citizenship Behaviors: A Review and Recommendations for Future Research. Journal of Organizational Behavior, 35: 87119. 
Rubin, S.R., Dierdorff, C.E., and Bachrach, G.D. (2013). Boundaries of Citizenship Behavior: Curviliniearity and Context in the Citizenship and Task Performance Relationship. Personnel Psychology, 66: 377-406.

Sawitri, D., Suswati, E., and Huda, K. (2016). The Impact of Job Satisfaction, Organization Commitment, Organization Citizenship Behavior (OCB) on Employees' Performance. International Journal of Organizational Innovation. 9: 24-45.

Stets, J. E., and Burke, P. J. (2000). Identity Theory and Social Identity Theory. Social Psychology Quarterly, 63(3), 224-237. 